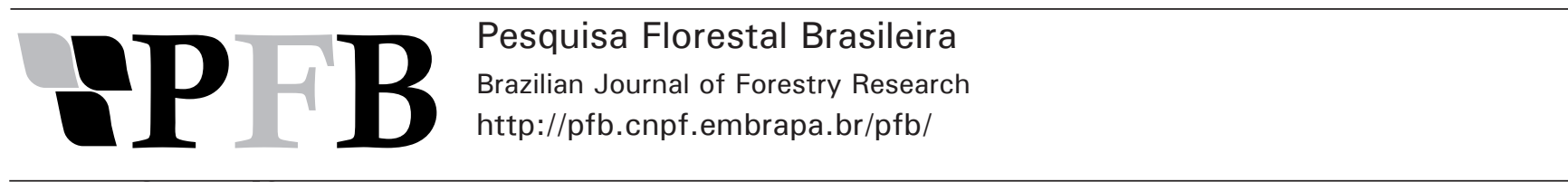

Nota Científica

\title{
Screening of rust and gall wasp in eucalypts species and provenances
}

\author{
Paulo Henrique Müller da Silva ${ }^{1 *}$, Rinaldo Cesar de Paula ${ }^{2}$, Aline Cristina Miranda ${ }^{3}$, Mario Luiz Teixeira de Moraes ${ }^{4}$, \\ Edson Luiz Furtado ${ }^{3}$, Cristiane de Pieri ${ }^{3}$, Jeremy Brawner ${ }^{5}$, David Lee ${ }^{5}$ \\ ${ }^{1}$ Instituto de Pesquisas e Estudos Florestais, Av. Pádua Dias 11, C. P. 530, CEP 13400-970, Piracicaba, SP, Brasil \\ ${ }^{2}$ Faculdade de Ciências Agrárias e Veterinárias, Universidade Estadual Paulista, Via de Acesso Prof. Paulo Donato Castellane, km 5, CEP 14.884-900, Jaboticabal, \\ SP, Brasil, Bolsista PQ 2-CNPq \\ ${ }^{3}$ Faculdade de Ciências Agronômicas de Botucatu, Rua José Barbosa de Barros, n 1780, C. P. 237, CEP 18.603-970, Botucatu, SP, Brasil \\ ${ }^{4}$ Faculdade de Engenharia de Ilha Solteira, Av. Brasil Centro, 56, C. P. 31, CEP 15385-000, Ilha Solteira, SP, Brasil \\ ${ }^{5}$ Forest Industries Research Centre, University of the Sunshine Coast, Maroochydore DC, 4558, Queensland, Australia
}

\begin{abstract}
"Autor correspondente:
paulohenrique@ipef.br

Termos para indexação:

Eucalyptus

Corymbia

Suscetibilidade

Puccinia psidii

Leptocybe invasa

Index terms:

Abstract - The present study investigated myrtle rust and gall wasp from noncommercial eucalypt taxa with potential to hybridization. We selected 38 genotypes from 18 species of Corymbia and Eucalyptus (Symphyomyrtus) genus. Two rust inoculations were evaluated using inoculums from rose apple and eucalypt, and natural gall occurrence in a high pest infestation condition. Corymbia was more susceptible to rust than Eucalyptus genus, and it was observed severity variation due to the sources of rust inoculum. Species that belong to Exsertaria and Transversaria (Latoangulatae) sections were more susceptible to gall wasp, and Corymbia species showed no development of gall.
\end{abstract}

Eucalyptus

Corymbia

Susceptibility

Puccinia psidii

Leptocybe invasa

Histórico do artigo:

Recebido em 12 jul 2014

Aprovado em 08 jun 2015

Publicado em 30 set 2015

doi: 10.4336/2015.pfb.35.83.746

\section{Avaliação da ferrugem e da vespa da galha em espécies e procedências de eucalipto}

\begin{abstract}
Resumo - Foi avaliada a ferrugem e a vespa da galha em táxons de eucalipto não comerciais com potencial para hibridização. Nós selecionamos 38 genótipos de 18 espécies dos gêneros Corymbia e Eucalyptus (Symphyomyrtus). Foram avaliadas duas inoculações de ferrugem com esporos provenientes de jambo e eucalipto e a ocorrência natural da vespa da galha em condições de alta infestação. Observou-se maior suscetibilidade à ferrugem em Corymbia do que em Eucalyptus e respostas diferentes às fontes de inóculo. Espécies das seções Latoangulatae e Exsertaria foram mais suscetíveis à vespa, e as espécies que pertencem ao gênero Corymbia não apresentaram desenvolvimento de galha.
\end{abstract}

Hundreds of eucalypt species are endemic in Australia and nearby islands; however, commercial eucalypt plantations have great importance worldwide. Nevertheless, just a few species and their hybrids are used in world plantations, especially those of the Symphyomyrtus subgenus (Potts \& Dungey, 2004; Harwood, 2011).

To obtain high productivity, genotypes have been selected to adapt to the environmental conditions, and plantations management features have been improved throughout the years (Gonçalves et al., 2012). However, pests and diseases may decrease the yield of commercial plantations. In Brazil and in other countries, myrtle rust represents an economic risk and threatens the biodiversity, damaging plants of Myrtaceae family (Silva et al., 2013). Another cause of damage on eucalypt stands in Brazil is gall wasp, which has caused significant damage to commercial stands and eucalypt nurseries since 2008 . 
Puccinia psidii (myrtle rust) is native to South America (Argentina, Brazil, Colombia, Ecuador, Paraguay, Uruguay, and Venezuela) and Central America (Alfenas et al., 2005), showing a wide distribution. This fungus represents a high risk due to its great potential to cause damage to plants of Myrtaceae family (Tommerup et al., 2003; Grgurinovic et al., 2006; Glen et al., 2007; Booth \& Jovanovic, 2012; Miranda et al., 2012). Although native to Brazil, this fungus started to affect the commercialization of Brazilian eucalypt stands in the $1980 \mathrm{~s}$.

Leptocybe invasa (blue gum chalcid), a pest insect of young eucalypt trees and seedlings, is native to Australia. A relatively narrow range of eucalypt hosts species was already described (Mendel et al., 2004; Thua et al., 2009), but the range of host species may be greater than already described, and it should be verified. This pest causes bump-shaped galls on petioles, stems, and leaves of young eucalypt trees. Severely affected trees show leaf fall, gnarled appearance and loss of growth. This insect ao invés de Gall is a global pest in eucalypts stands. In Brazil it has spread to several states, causing significant damages in nursery and field conditions.

Hybridization in Eucalyptus genus is commonly used to obtain a superior genotype in genetic improvement programs. There is a great potential for intra and interspecific hybridized eucalypts that could be cloned for commercial plantations, after an appropriate selection process. Gaining knowledge about behavior of potential species and provenances is important component of this selection process for commercial genotypes.

This study aimed to carry out an initial screening of taxa from genus Corymbia and Eucalyptus to investigate susceptibility to Puccinia psidii, using inoculum from two hosts (rose apple and eucalypt), and to verify galls formation (L. invasa).

Thirty eight taxa from 18 species of Corymbia and Eucalyptus were chosen, all of Eucalyptus species belonged to Symphyomyrtus subgenus (Table 1). Some seeds were imported from Australia in 2012 and others were collected in Brazil.

. Some seeds were imported from Australia in 2012 and others were collected in Brazil.
Table 1. Description of species and number of provenances.

\begin{tabular}{|c|c|c|c|c|}
\hline Number & Genus & Species & $\begin{array}{l}\text { Subgenus and } \\
\text { section }\end{array}$ & Provenances \\
\hline 1 & Corymbia & $\begin{array}{l}\text { citriodora } \\
\text { citriodora }\end{array}$ & Ochraria & 2 \\
\hline 2 & Corymbia & citriodora variegata & Ochraria & 10 \\
\hline 3 & Corymbia & henryi & Ochraria & 2 \\
\hline 4 & Corymbia & torelliana & Ochraria & 1 \\
\hline 5 & Eucalyptus & amplifolia & $\begin{array}{l}\text { Symphyomyrtus } \\
\text { Exsertaria }\end{array}$ & 2 \\
\hline 6 & Eucalyptus & argophloia & $\begin{array}{l}\text { Symphyomyrtus } \\
\text { Adnataria }\end{array}$ & 1 \\
\hline 7 & Eucalyptus & brassiana & $\begin{array}{l}\text { Symphyomyrtus } \\
\text { Exsertaria }\end{array}$ & 1 \\
\hline 8 & Eucalyptus & brookeriana & $\begin{array}{l}\text { Symphyomyrtus } \\
\text { Maidenaria }\end{array}$ & 1 \\
\hline 9 & Eucalyptus & camaldulensis & $\begin{array}{l}\text { Symphyomyrtus } \\
\text { Exsertaria }\end{array}$ & 1 \\
\hline 10 & Eucalyptus & cladocalyx & $\begin{array}{l}\text { Symphyomyrtus } \\
\text { Aenigmataria }\end{array}$ & 1 \\
\hline 11 & Eucalyptus & crebra & $\begin{array}{l}\text { Symphyomyrtus } \\
\text { Adnataria }\end{array}$ & 1 \\
\hline 12 & Eucalyptus & longirostrata & $\begin{array}{l}\text { Symphyomyrtus } \\
\text { Transversaria }\end{array}$ & 4 \\
\hline 13 & Eucalyptus & macarthurii & $\begin{array}{l}\text { Symphyomyrtus } \\
\text { Maidenaria }\end{array}$ & 1 \\
\hline 14 & Eucalyptus & major & $\begin{array}{l}\text { Symphyomyrtus } \\
\text { Transversaria }\end{array}$ & 4 \\
\hline 15 & Eucalyptus & moluccana & $\begin{array}{l}\text { Symphyomyrtus } \\
\text { Adnataria }\end{array}$ & 3 \\
\hline 16 & Eucalyptus & occidentalis & $\begin{array}{l}\text { Symphyomyrtus } \\
\text { Bisectaria }\end{array}$ & 1 \\
\hline 17 & Eucalyptus & thozetiana & $\begin{array}{l}\text { Symphyomyrtus } \\
\text { Adnataria }\end{array}$ & 1 \\
\hline \multirow[t]{2}{*}{18} & Eucalyptus & urophylla & $\begin{array}{l}\text { Symphyomyrtus } \\
\text { Transversaria }\end{array}$ & 1 \\
\hline & & & Total & 38 \\
\hline
\end{tabular}

The seedlings were produced in the municipality of Piracicaba, São Paulo State, Brazil, in IPEF Nursery, from September 2012 to January 2013. Commercial production protocol was used. Seeds were sowed directly in the containers (polypropylene tubes of 50 $\mathrm{cm}^{3}$ ), with a mixture: rice hulls, coconut fiber, and vermiculite. The fertilization was performed four times a week with a solution of Calcium nitrate $450 \mathrm{~g}$; Ammonium nitrate $300 \mathrm{~g}$; Mono Ammonium Phosphate (MAP) 250 g; Potassium nitrate 300 g; Magnesium 
sulfate $250 \mathrm{~g}$; Ammonium sulfate $250 \mathrm{~g}$; Tenso iron $2.5 \mathrm{~g}$; Manganese sulfate $0.85 \mathrm{~g}$; Boric Acid $0.75 \mathrm{~g}$; Zinc sulfate $0.325 \mathrm{~g}$; Copper sulfate $0.1 \mathrm{~g}$; and Sodium molybdate $0.005 \mathrm{~g}$ in $1000 \mathrm{~L}$ of water.

In January 2013,10 seedlings $(\approx 90$ days old $)$, per taxa, were inoculated with rust spores. This experiment was conducted in duplicate, one with inoculums from Syzygium jambos $\left(7.2 \times 10^{4}\right.$ spores $\left.\mathrm{mL}^{-1}\right)$ and another from Eucalyptus urophylla $\left(7.6 \times 10^{4}\right.$ spores $\left.\mathrm{mL}^{-1}\right)$. Urediniospores were collected with a brush (Tiger ${ }^{\circledR}$ ) number 6, soft bristle and placed in Petri dishes. After collection, they were separately suspended in distilled water containing $0.05 \%$ of Tween 80 and were sprayed at the leaves. After inoculation, the plants were kept in control conditions with temperature of $21^{\circ} \mathrm{C} \pm 1{ }^{\circ} \mathrm{C}$ and $80 \%$ air moisture, with nebulization every $30 \mathrm{~min}$ and photoperiod of $12 \mathrm{~h}$.

Latent period, incidence and disease severity were evaluated (Castro et al., 1983; Ruiz et al., 1989), according to Coutinho \& Figueiredo's (1984) scale, adapted by Pieri (2012).

Natural infestation of gall wasp was also evaluated, and no control was applied until the occurrence observation was carried out in the nursery during January/February, 2013. We evaluated 20 seedlings per genotype and classified a genotype as "susceptible" when at least one seedling exhibited galls caused by Leptocybe invasa.

It was observed more susceptibility to rust in Corymbia genus than in Eucalyptus, different responses in eucalypt taxa to the sources of rust inoculum (rose apple and eucalypt sources), and differences among provenances within the species for the same rust inoculum. Signs of pathogen occurrence (latent period) were visible 12 days after inoculation in all susceptible taxa for both inoculums. There was a genetic interaction of disease and eucalypt species and provenance. Corymbia citriodora variegata from Brooyar was the most susceptible taxa to rust collected from the eucalypt source but it did not show susceptibility to rust from rose apple. Corymbia citriodora citriodora from Kirrima showed no symptom to rust from eucalypts, however it was the most susceptible to rust from rose apple, showing high sporulation of pustules in all plants. All Eucalyptus genus seedlings exhibited high resistance, with hypersensitivity reactions observed only in E. brookeriana and E. crebra under inoculation of rust from apple rose. E. crebra showed hypersensitivity reaction in $20 \%$ of the plants, whereas E. brookeriana showed it in all plants (Table 2).
Taxa significantly differ in terms of tolerance (Van Heerden \& Wingfield, 2002). Thus, rust genotypic interaction with eucalypt taxa is an important knowledge to drive eucalypt conservation or strategies in breeding program, and biological research is important to manage rust in eucalypt stands (Yamaoka, 2014). Rust shows rapid development that overcome resistance in short time (Samils et al., 2011). Resistance breakdown could quickly occur where there is high genetic variability of fungus, leading to a greater recombination potential among pathogens (Graça et al., 2011). Genetic variability is commonly low in sites where Puccinia psidii was recently introduced (Zhong et al., 2011). However, in Brazil, a considerable genetic rust diversity is observed, which is strongly related to host genotypes (Graça et al., 2011).

Another important fact for breeding programs is the ecological zoning of eucalypt rust that may provide useful information by indicating risk classes of disease and occurrence in the field (Masson et al., 2007; Booth \& Jovanovic, 2012; Silva et al., 2013).

Many taxa were susceptible to gall wasp - more than $50 \%$ of studied eucalypts showed gall development. In Eucalyptus genus it was observed that $2 / 3$ of the species were susceptible with higher levels of Leptocybe invasa susceptibility for species's that belong to Exsertaria and Transversaria (Latoangulatae) sections while no development of gall was found in the Corymbia species tested. Only four species of Eucalyptus showed no gall wasp development: E. argophloia, E. brookeriana, E. crebra and E. urophylla. Provenances also influence specie susceptibility to gall wasp. E. moluccana showed one susceptible provenance of the three evaluated (Table 2).

The results observed in seedling nursery is an indicative, but field infestation can be different. Thua et al. (2009) studied 18 species of eucalypts and observed gall occurrence in 13 species from six sections of Eucalyptus and one species of Corymbia. However, five species that showed susceptibility in the nursery were not damaged in the field as even the most susceptible species may have variation in susceptibility among provenances.

In Brazil, E. camaldulenis is an important species for dry areas as a parent of hybrids with E. grandis and/ or E. urophylla. Gall wasp caused severe damage to commercial stands of E. camaldulensis when planted as pure species or hybridin the parentage of a hybrid. Therefore, study of species with drought tolerance should encompass susceptibility to gall as well. 
Table 2. Rust and gall susceptibility in eucalypts genotypes.

\begin{tabular}{|c|c|c|c|c|c|c|}
\hline \multirow[t]{2}{*}{ Cod } & \multirow[t]{2}{*}{ Species } & \multirow[t]{2}{*}{ Section } & \multirow[t]{2}{*}{ Provenance } & \multicolumn{2}{|c|}{ Rust (rate) } & \multirow[t]{2}{*}{ Gall } \\
\hline & & & & Rose apple & Eucalypt & \\
\hline 1 & C. citriodora citriodora & Ochraria & Yeppoon & 1 & $4(40 \%)$ & $\mathrm{NE}$ \\
\hline 2 & C. citriodora citriodora & Ochraria & Kirrima & $5(100 \%)$ & 1 & $\mathrm{NE}$ \\
\hline 3 & C. citriodora variegata & Ochraria & Barakula S.F. & $4(40 \%)$ & $4(40 \%)$ & $\mathrm{NO}$ \\
\hline 4 & C. citriodora variegata & Ochraria & Saddler Springs & $4(40 \%)$ & $4(20 \%)$ & $\mathrm{NE}$ \\
\hline 5 & C. citriodora variegata & Ochraria & Richmond Range & 1 & 1 & NO \\
\hline 6 & C. citriodora variegata & Ochraria & Barclays Deniliquin & 1 & $4(20 \%)$ & NO \\
\hline 7 & C. citriodora variegata & Ochraria & Wolvi & 1 & $4(40 \%)$ & $\mathrm{NE}$ \\
\hline 8 & C. citriodora variegata & Ochraria & Brooyar & 1 & $5(80 \%)$ & $\mathrm{NE}$ \\
\hline 9 & C. citriodora variegata & Ochraria & Woondum & 1 & $4(20 \%)$ & NO \\
\hline 10 & C. citriodora variegata & Ochraria & Cherry Tree & 1 & $4(20 \%)$ & $\mathrm{NE}$ \\
\hline 11 & C. citriodora variegata & Ochraria & Woondum & 1 & $4(20 \%)$ & $\mathrm{NO}$ \\
\hline 12 & C. citriodora variegata & Ochraria & Anhembi, SP - BR & 1 & $4(40 \%)$ & NO \\
\hline 13 & C. henryi & Ochraria & Lockyer & 1 & $4(40 \%)$ & NO \\
\hline 14 & C. henryi & Ochraria & Myrtle & 1 & 1 & $\mathrm{NE}$ \\
\hline 15 & C. torelliana & Ochraria & Anhembi, SP - BR & 1 & 1 & NO \\
\hline 16 & E. amplifolia & Exsertaria & Nerong S.F. & 1 & 1 & OB \\
\hline 17 & E. amplifolia & Exsertaria & Clouds Ck Sf \& Tsr & 1 & 1 & OB \\
\hline 18 & E. argophloia & Adnataria & & 1 & 1 & NO \\
\hline 19 & E. brookeriana & Maidenaria & Otways & $2(100 \%)$ & 1 & NO \\
\hline 20 & E. cladocalyx & Aenigmataria & & 1 & 1 & $\mathrm{NE}$ \\
\hline 21 & E. crebra & Adnataria & Nw Baradine Po & $2(20 \%)$ & 1 & NO \\
\hline 22 & E. longirostrata & Transversaria & Starkvale Creek & 1 & 1 & OB \\
\hline 23 & E. longirostrata & Transversaria & & 1 & 1 & OB \\
\hline 24 & E. longirostrata & Transversaria & Diamondy & 1 & 1 & OB \\
\hline 25 & E. longirostrata & Transversaria & Coominglah & 1 & 1 & OB \\
\hline 26 & E. macarthurii & Maidenaria & Paddys River, Nsw & 1 & 1 & OB \\
\hline 27 & E. major & Transversaria & Se Gympie & 1 & 1 & OB \\
\hline 28 & E. major & Transversaria & Blackdown Tableland & 1 & 1 & OB \\
\hline 29 & E. major & Transversaria & & 1 & 1 & OB \\
\hline 30 & E. major & Transversaria & Brooweena & 1 & 1 & OB \\
\hline 31 & E. moluccana & Adnataria & Crediton S.F. & 1 & 1 & NO \\
\hline 32 & E. moluccana & Adnataria & Mt Garnet & 1 & 1 & NO \\
\hline 33 & E. moluccana & Adnataria & Ravenshoe & 1 & 1 & OB \\
\hline 34 & E. occidentalis & Bisectaria & & 1 & 1 & $\mathrm{NE}$ \\
\hline 35 & E. thozetiana & Adnataria & Clermont & 1 & 1 & $\mathrm{NE}$ \\
\hline 36 & E. camaldulensis & Exsertaria & Selviria, MS - BR & 1 & 1 & OB \\
\hline 37 & E. brassiana & Exsertaria & Urbano Santos, MA - BR & 1 & 1 & OB \\
\hline 38 & E. urophylla & Transversaria & Avaré, $\mathrm{SP}-\mathrm{BR}$ & 1 & 1 & $\mathrm{NO}$ \\
\hline
\end{tabular}

NE - No evaluation; NO - Not observed; OB - Observed; Rust classification 1 to 5. (1) Total absence of symptoms or hypersensitivity reaction; (2) Reaction to hypersensitivity and/or bronzing of leaves; (3) Injury not showing pustules; (4) injury with little spore pustules; (5) Injury presenting highly sporulating pustules. 


\section{Conclusions}

C. torelliana, E. argophloia, E. crebra, two provenance of $E$. moluccana and one provenance of $C$. citriodora variegata showed good results for rust and gall wasp resistance, thus, these species could be a good choice to start new hybrids combinations.

\section{Acknowledgments}

We would like to thank Arborgen, Aperan, Copener, Duratex, Eldorado, Eucatex, Fibria, Forestal Oriental, Gerdau, Jari, Klabin, Lwarcel, Melhoramentos, Palmasola, Stora Enso, Suzano, Weyerhaeuser Uruguay and Vallourec (companies member of Programa Cooperativo de Melhoramento Florestal [Forest Improvement Cooperative Program] - IPEF), University of São Paulo - USP/ESALQ, São Paulo State University - UNESP for their support and the reviewers/editors for the contributions that improved the manuscript.

\section{References}

ALFENAS, A. C.; ZAUZA, E. A. V.; WINGFIELD, M. J.; ROUX, J.; GLEN, M. Heteropyxis natalensis, a new host of Puccinia psidii rust. Australasian Plant Pathology, v. 34, n. 2, p. 285-286, 2005. DOI: 10.1071/AP05023

BOOTH, T. H.; JOVANOVIC, T. Assessing vulnerable areas for Puccinia psidii Eucalyptus rust in Australia. Australasian Plant Pathology, v. 41, n. 4, p. 425-429, 2012. DOI: 10.1007/s13313012-0130-x

CASTRO, H. A.; KRUGNER, T. L.; IDERIHA, C. H. F.; CAPELLO, M. S. C.; MARCHI, A. B. Inoculação cruzada de Eucalyptus, Psidium guajava (Psidium guajava), jambeiro (Syzygium jamboss) com Puccinia psidii. Fitopatologia Brasileira, Brasília, DF, v. 8, n. 3, p. 491-497, 1983.

COUTINHO, L. M.; FIGUEIREDO, M. B. Estudos sobre especializações fisiológicas em Puccinia psidii Winter. Summa Phytopathologica, Jaguariuna, v. 10, n. 1, p. 55-56, 1984.

GLEN, M.; ALFENAS, A. C.; ZAUZA, E. A. V.; WINGFIELD, M. J.; MOHAMMED, C. Puccinia psidii a threat to the Australian environment and economy: a review. Australasian Plant Pathology, v. 36, p. 1-16, 2007. DOI: 10.1071/AP06088

GONÇALVES, J. L. M.; ALVARES, C. A.; HIGA, A. R.; SILVA, L. D.; ALFENAS, A. C.; STAHL, J.; FERRAZ, S. F. B.; LIMA, W. P.; BRANCALION, P. H. S.; HUBNER, A.; BOUILLET, J. P. D.; LACLAU, J. P.; NOUVELLON, Y.; EPRON, D. Integrating genetic and silvicultural strategies to minimize abiotic and biotic constraints in Brazilian eucalypt plantations. Forest Ecology and Management, Amsterdam, v. 301, n. 1, p. 6-21, 2012. DOI: 10.1016/j.foreco.2012.12.030
GRAÇA, R. N.; ALFENAS, A. C.; ROSS-DAVIS, A. L; KLOPFENSTEIN, N. D.; KIM, M.-S.; PEEVER, T. L.; CANNON, P. G.; UCHIDA, J. Y.; KADOOKA, C. Y.; HAUFF, R. D. Multilocus genotypes indicate differentiation among Puccinia psidii populations from South America and Hawaii. In: ANNUAL WESTERN INTERNATIONAL FOREST DISEASE WORK CONFERENCE, 58., 2010, Valemount. Proceedings... Valemount: WIFDWC, 2011. p. 131-134.

GRGURINOVIC, C. A.; WALSH, D.; MACBETH, F. Eucalyptus rust caused by Puccinia psidii and the threat it poses to Australia. OEPP/EPPO Bulletin, Paris, v. 36, n. 3, p. 486-489, 2006. DOI: 10.1111/j.1365-2338.2006.01048.x

HARWOOD, C. New introductions: doing it right. In: WALKER, J. Developing a eucalypt resource. Learning from Australia and elsewhere. New Zealand: Wood Technology Research Centre, University of Canterbury, 2011. p. 125-136.

MASSON, V. M.; OHTO, C. T.; FURTADO, E. L.; SILVA, A. S. Zoneamento climático do eucalipto no estado de São Paulo visando o controle da ferrugem. Summa Phytopathologica, v. 33, p. 58-67, 2007.

MENDEL,Z:; PROTASOV,A.; FISHER, N.; LASALLE, J. Taxonomy and biology of Leptocybe invasa (Eulophidae:Hymenoptera) an invasive gall inducer on eucalyptus. Australian Journal of Entomology, v. 43, p. 101-113, 2004

MIRANDA, A. C.; MORAES, M. L. T.; MORI, E. S.; TAMBARUSSI, E.; FURTADO, E. L.; SILVA, P. H. M.; SEBBENN, A. M. Heritability for resistance to Puccinia psidii Winter rust in Eucalyptus grandis Hill ex Maiden in Southwestern Brazil. Tree Genetics and Genomics, v. 9, n. 2, p. 321-329, 2012.

PIERI, C. Caracterização de Puccinia psidii, identificação de mirtáceas diferenciadoras de raças fisiológicas e estudos anatômicos do limbo foliar relacionados à resistência. 2012. 186 f. Dissertação (Mestrado em Ciência Florestal) - Universidade Estadual Paulista, Botucatu.

POTTS, B. M.; DUNGEY, H. S. Hybridization of Eucalyptus: key issues for breeders and geneticists. New Forests, Dordrecht, v. 27 , n. 2, p. 115-138, 2004.

RUIZ, R. A. R. et al; ALFENAS, A. C.; FERREIRA, F. A.; VALE, F. X. R. Influência da temperatura, do tempo de molhamento foliar, fotoperíodo e da intensidade de luz sobre a infecção de Puccinia psidii, em Eucalyptus cloeziana. Fitopatologia Brasileira, Brasília, DF, v. 14, n. 1, p. 55-61, 1989.

SAMILS, B.; RÖNNBERG-WÄSTLJUNG, A. C.; STENLID, J. QTL mapping of resistance to leaf rust in Salix. Tree Genetics and Genomics, v. 7, n. 6, p. 1219-1235, 2011. DOI: 10.1007/s11295011-0408-0

SILVA, P. H. M.; MIRANDA, A. C.; MORAES, M. L.T.; FURTADO, E. L.; STAPE, J. L.; ALVARES, C. A.; SENTELHAS, P. C.; SEBBENN, A. Selecting for rust (Puccinia psidii) resistance in Eucalyptus grandis in São Paulo State, Brazil. Forest Ecology and Management, Amsterdam, v. 303, n. 1, p. 91-97, 2013. DOI: 10.1016/j.foreco.2013.04.002 
THUA, P. Q.; DELL, B.; BURGESS, T. I. Susceptibility of 18 eucalypt species to the gall wasp Leptocybe invasa in the nursery and young plantations in Vietnam. Science Asia, v. 35, n. 2, p. 113$117,2009$.

TOMMERUP, I. C.; ALFENAS, A. C.; OLD, K. M. Guava rust in Brazil-a threat to Eucalyptus and other Myrtaceae. New Zealand Journal of Forestry Science, v. 33, n. 3, p. 420-428, 2003.

VAN HEERDEN, S. W.; WINGFIELD, M. J. Effect of environment on the response of Eucalyptus clones to inoculation with Cryphonectria. Forest Pathology, v. 32, n. 6, p. 395-402, 2002.
YAMAOKA, Y. Recent outbreaks of rust diseases and the importance of basic biological research for controlling rusts. Journal of General Plant Pathology, v. 80, n. 5, p. 1-14, 2014. DOI: 10.1007/s10327014-0529-Z

ZHONG, S.; YANG, B.; PURI, K. D. Characterization of Puccinia psidii isolates in Hawaii using microsatellite DNA markers. Journal of General Plant Pathology, v. 77, n. 3, p. 178-181, 2011. DOI: 10.1007/s10327-011-0303-4 